\title{
Migration theatre in South Africa with reference to Mike van Graan's When
}

swallows cry

\section{Summary}

In this article a discussion on migrant theatre in South Africa is given, with special reference to Mike van Graan's play When Swallows Cry (2017). In the introduction a short background is given in terms of migration statistics and issues (notably xenophobia) pertaining to the South African state and society. Against the background of an international and national upsurge in migrant theatre the view is expressed that though we have had migrant theatre pre-1994 during the heyday of Nationalist apartheid ideology, a change has occurred since 1994 when the political dispensation changed in South Africa and the African National Congress (ANC) came into power. The situation today is more complex where intracontinental and cross-continental migrancy is now part of everyone's lives, as portrayed in Mike van Graan's When Swallows Cry.

Van Graan's play thus reflects a changing focus in migrant plays in South Africa: from the very early plays concerned with internal migration in the country to plays that today reflect a more complex world (i.e. the often violent and xenophobic experiences of African migrants - also within a so-called new South Africa, but also in the rest of Africa and the bigger world). 


\section{Opsomming}

In hierdie artikel word 'n bespreking van migrasieteater in Suid-Afrika gegee met spesiale verwysing na Mike van Graan se drama, When Swallows Cry (2017). In die inleiding word 'n kort agtergrond gegee van migrasie-statistieke, asook die probleme geassosieer daarmee (onder meer, xenofobie) met verwysing na die SuidAfrikaanse regering en gemeenskap. Teen die agtergrond van 'n internasionale en nasionale toename in migrasieteater word die beskouing gehuldig dat, hoewel ons migrasieteater gehad het voor 1994 gedurende die hoogbloei van die Nasionale Party se apartheidsideologie, 'n verandering ingetree het sedert 1994 toe die ANC die politieke mag in Suid-Afrika oorgeneem het. Die situasie is tans meer kompleks met intra-kontinentale en kruis-kontinentale migrasie wat nou deel is van ons almal se lewens, soos wat Mike van Graan in When Swallows Cry ook uitbeeld.

Van Graan se drama weerspieël dus 'n veranderende fokus in migrasieteater in Suid-Afrika: vanaf die vroeë dramas wat hoofsaaklik gehandel het oor interne migrasie in die land tot dramas wat vandag 'n meer komplekse wêreld reflekteer (naamlik die dikwelse geweldadige en xenofobiese ervarings van Afrika-migrante binne die sogenaamde nuwe Suid-Afrika, maar ook in die res van Afrika en die wêreld daar buite). 


\section{Introduction}

Even when we exclude its non-human forms, 'migration' is a word that encompasses a lot. What we can say is that whether it is thought of in terms of individuals (immigrant, expatriate, temporary worker, exile, refugee, itinerant cosmopolitan, nomad, et cetera) or collectives (colonial settlement, diaspora, slave or convict transportation, trafficking, displacement), migration is, at its heart, about encounters with foreignness - with foreign people, and with foreign places. These are, it may be supposed, ingredients of good storytelling (Cox 2014: 3).

A historical overview of South Africa from the perspective of migration will have to mention the whole history of people coming to this country: from the first Khoisan inhabitants in the Cape, the migrating black tribes from the north, the arrival of the first Europeans (the Dutch colonists in 1652, the British settlers from 1820), the importation of slaves from Malay, Indonesia, and others during colonial rule, till the more recent migration from neighbouring countries (Zimbabwe, Mozambique, Angola) and further north in Africa (Somalia, Ethiopia, Democratic Republic of the Congo, and others). 
The influx of various nationalities and races to this country over a period of hundreds of years, as well as political and economic changes and developments during these years, led to a situation that is currently full of ironic complexities.

While one would have expected, that after the demise of the Nationalist Party and its ideology of apartheid in 1994 and the African National Congress (ANC) came into power, to see an influx of migrants from the neighbouring countries, few people would have predicted the upsurge in xenophobic attacks that followed in its wake. In many of the neighbouring countries - notably Zimbabwe and Mozambique - decades of political turmoil had led to failed economies. Citizens of neigbouring countries hoped that in a new South Africa (led by the South-African freedom fighters and supported by these neigbouring countries) that South-Afrcan would welcome them with open arms after the struggle has been completed.

An increase of migrants (legal and illegal) started to flood South Africa after 1994. Although it is very difficult to get reliable census numbers from government institutions regarding migration numbers, a group called Africa Check (an independent non-partisan fact-checking organisation) does release regular reports and factsheets relating to migration in southern Africa (from claims on asylum seekers and refugees to data on economic migrants). The reasons for the unreliability of much of the current official migration data, according to Africa Check (2017: 1) are as follows: 
In previous reports, experts have told us that accurate or precise information on migrant populations in South Africa is hard to obtain because of inadequate data collection systems and irregular migration patterns. Another reason is that both governments and non-governmental organisations have vested interest in exaggerating immigrant numbers, either to justify stricter immigration controls or secure increased donor funding.

According to them the South African media often uses anecdotal information to create sensational headlines rather than real data, to sketch a situation of large immigration numbers (for example, 1.5 million Zimbabweans or almost a third of Malawi's population, that is, if true 6 million people) living in South Africa. This anecdotal "evidence" is often used in the negative rhetoric one commonly finds within poor communities who say that foreigners are stealing their jobs, committing crimes and putting South African resources under pressure.

In the 2011 government census report it was stated that more than $75 \%$ of foreignborn (international) migrants living in South Africa came from the rest of Africa and the vast majority from SADC (that is, the Southern African region, with Lesotho the highest by proportion: almost half of Basotho men work in South Africa). 
Africa Check quotes from a Stats SA report the following reason for this "consistently high number of migration from SADC countries", as being 'due to a colonial and apartheid-era regional history of labour migration, especially from Mozambique, Lesotho, Malawi, Zimbabwe and Swaziland" (2017: 1). The Stats SA report also states that South Africa is regarded as an "important destination for many people who seek better socio-economic opportunities due to its relatively stable democratic government, good infrastructure and economic stability". The economy of the country is a mix of first and third world economies and is seen to be one of the richest countries on the African continent.

The highly publicised xenophobic attacks in 2008 across South Africa have, according to later reports, however, led to a sharp decline in new migrants coming from SADC or other African countries to South Africa. Despite condemnations from the ruling African National Congress, xenophobic attacks on other Africans by South African Africans is a continuous problem and one that is often reported in the South African media - even today.

Since the notorious 2008 xenophobic attacks on migrants, the situation has not improved in South Africa and instead seems to have deteriorated further, with an upsurge in April 2015 of violent attacks in Durban which also spread to other parts of the country. According to Crush and Tawodzera (2014: 656) during the 2008 
attacks approximately 100, 000 people were displaced, while at least 60 people died. According to Erwin (2017: 9):

These attacks (2008 - MK) were in the majority aimed at people seen as belonging to other African countries, the legal status of people appeared irrelevant when identifying, and then terrorizing victims. People targeted as 'foreign' also came from neighbouring countries such as Zimbabwe and Mozambique (many of whom are now permanent residents or citizens), and even South Africans who according to the attacker do not 'sound' or 'look' like they come from here. In the 2015 attacks, for the first time, Pakistani and Bangladeshi shop owners in Durban were also threatened.

Today one finds regular reports on xenophobic attacks, while media attention is currently also focused on the impasse found at the Central Methodist Mission on Greenmarket Square in Cape Town, where a large group of migrants (describing themselves as refugees) has been living outside the church (under deteriorating circumstances) since September 2019. It seems as if even interventions from the UNCHR have not been successful.

Various reasons for the current dire situation regarding migrants in South Africa can be put forward. Kira Erwin (2017)in her Literature review entitled, Migration 
and the inclusive city: Migration and social inclusion higlights two reasons, namely, bureaucratic and legal problems/inefficiencies, and economic inequalities.

Erwin (2017: 6-7) gives an overview of the various protocols on migration within SADC countries. These include the 2016 Green paper on international Migration and Acts like the Aliens Control Act of 1991 that was repealed in 2002 and replaced with the new Immigration Act in 2005. Some protocals and acts on the migration issue were never finalized and others not well implemented. With the current Central Methodist Mission Church (Cape Town) fiasco it is clear that legal issues regarding migration, are still not comprehensively dealt with within the South African legal system. Erwin (2017: 8) and others (inter alia, Peberdy, 2001) mention the irony embedded in the current situation:

While racism is no longer legislated, democratic South Africa has a continued emphasis on different social, cultural and even moral spheres associated with spatial geographies and categories of people. Indeed the ways in which foreign black Africans are superficially identified has disturbing consistencies with the apartheid past.

An important part of of the global and local debate on migration has to do with the universal ideals of equality and human rights - for the migrant, but also for the citizen of the state. According to Erwin (2017: 5): 
Therefore, how a state chooses to identify and manage migration flows has important relevance not just for people categorized as legal or illegal immigrants or refugees, but for citizens of the state as well. Indeed, national responses to migration are fundamentally questions of what it means to be human in a specific part of the world.

The link between xenophobic attacks and the economic inequalities found in South Africa is also highlighted by a number of authors as a second reason why migrants are often deemed unwelcome in South Africa. The downturn in the economy the last few years has exacerbated general anti-migrant attitude in the country, and especially in poorer communities. According to Pernegger (2015: 65) many of the service delivery protests seen in the country against poor government services and corruption "often have within them groups voicing anti-foreigner sentiments". Erwin (2017: 10) mentions that a number of theorists have tried to explain this situation by coining a phrase: "relative deprivation theory". This theory postulates that people (a group of people who feel economically deprived) can unfavourably compare themselves to another group (migrants) and this can generate feelings of deprivation which then generates hostility against the so-called "outgroup".

Contemporary drama and theatre studies also respond to how these issues are performed globally and nationally. The influential IFTR (The International Federation for Theatre Research) organization focused in their World Congress 
held in Belgrade (Serbia) from 9 - 13 July 2018 on the theme of Theatre and Migration (Theatre, Nation and Identity: Between migration and stasis). The complexity of all the issues found in migration experiences and how they can be portrayed on stage can be seen in the four questions asked by the conference organizers in the Introduction (5) to the conference programme:

How have theatre and performance responded to issues of exile, displacement and Otherness both historically and in our times? How has the process of migration been shaped and reshaped through various political, social, cultural and artistic scenarios? How can the notion of migration be employed to grapple with issues of cultural cross-fertilization, transfer, appropriation and mutation? What constitutes ecologies of migration in theatre and performance (and beyond).

In the next section the focus is on migration theatre in South Africa: from a short introduction to the first examples (plays) found during the period when the National Party's ideology of apartheid permeated the lives and worlds of all black South Africans, to the post 1994 period when intra-continental and crosscontinental migrancy is now part of everyone's lives as portrayed in Mike van Graan's When Swallows Cry.

South African migrant theatre: pre- 1994 and post-1994 
Since labour migrants have been part of the South African socio-historical context for a long time, i.e. either working as farm labourers or as miners at the gold or diamond mines, one finds already in the 1970s examples of South African plays reflecting this reality. In his discussion of black performance in the period $1973-$ 1986 Peterson (1994: 44) summarizes the themes prevalent in that period:

The themes of oppression and exploitation in South Africa have been the major concern of black performance. The most frequent depictions have been those of pass arrests, the humiliation experienced at the medical examinations conducted at the labour bureau, petty bureaucracy, police violence, prison conditions, examples of racial discrimination, the struggles of migrant workers, conditions in the hostel compounds, and the breakdown of moral and cultural values in the townships.

Athol Fugard, John Kani and Winston Ntshona's Sizwe Banzi is Dead, (1972) also reflects the political reality of the 1970's where the Bantu homeland and pass system determined many black people's identity, as well as where they can go, stay and work. Another well-known example of how migrant workers experienced life during this period, is Maishe Maponya's The Hungry Earth (1979). Since the 1970's was still in the heyday of apartheid, the play places the exploitation of black workers by white mine managers clearly within this political context. In 
Zakes Mda's The Hill (for which he received the Amstel playwright of the year award in 1979), the plight of migrant workers in Lesotho is portrayed.

In her study of the Worker's Theatre movement in South Africa in the 1980's in Natal, Astrid von Kotze (1988) also mentions and discusses plays dealing with migrancy (for example, Why Lord? and Once Bitten, Twice shy), where the impact on family life, as well as the contradictions experienced by the characters between urban life and traditional beliefs are portrayed.

It is not only black people who were affected by apartheid laws during the 1960's to 1980 's, but also so-called coloured people were displaced with the implementation of the Groups Areas Act, which led to the notorious District Six removals in Cape Town. The socio-economic and political effects of this ideology were reflected in Adam Small's Kanna hy kô hystoe (1965). Interestingly the family portrayed in the play put their hope for a better future on the figure of Kanna - the one person who was able to escape the dire socio-economic realities of the family by becoming himself a migrant (only returning from overseas for the funeral of Makiet, before going back to his new home). In the play this distinction is shown in the use of language: the family speaks Kaaps Afrikaans (they see Kanna's return as a return to their home, he is coming hystoe), while Kanna talks a more formal Afrikaans when informing the family that he is not staying in South Africa, but going back to his new "home" (huis toe). 
In Afrikaans Elsa Joubert's acclaimed novel, Die Swerfjare van Poppie Nongena (1978), was adapted as an Afrikaans play, Poppie - die Drama (1984) by Elsa Joubert and Sandra Kotzé, also translated into English by Elsa Joubert (The Long Journey of Poppie Nongena, 1980). It has since been translated into various other languages and has played overseas to great acclaim. A film by Christiaan Olwagen based on the play has been released in 2020 (Poppie Nongena). Elsa Joubert's documented the real life story of an Afrikaans speaking isiXhosa mother during the 1970's and her struggles to keep her family together during this period when pass laws dictated the lives of black people.

In this short overview it is already clear that the pre-1994 situation was influenced to a large degree by the ideology of apartheid (and all the legislation regarding the movement and placement of people encompassed in that ideology) and how even black or coloured South Africans became migrants in their own country.

Today the picture is different and more complex. Fleishman (Introduction to The Magnet Theatre "Migration" plays, 2012: 6) states:

The end of apartheid and the advent of democracy have resulted in the forceful reintegration of South Africa in the global economy. One result of this has been the development of a new migratory sub-system centred on South Africa. Rather than attracting international migration from Europe and 
Asia, as has been the case prior to 1994, this new system attracts migrants from surrounding states in sub-Saharan Africa and seems to be intimately connected to the existence of the Southern African Development Community (SADC). At the same, internal circular migration patterns set up during apartheid, rather than declining post-1994, have continued to grow.

A large contribution in terms of contemporary South African migrant theatre has been made by the Cape-based group, Magnet Theatre - an award-winning South African physical theatre company. The company was established in 1987 under the directorship of Mark Fleishman, Jennie Reznek and Mandla Mbothwe and has since then produced many well-known plays (inter alia Every Year, Every Day, I am walking; Ingcwaba Lendoda Lise Cankwe Ndlela/The Grave of the Man is next to the Road; Die Vreemdeling/The Foreigner; Inxeba Lomphilisi/The Wound of a Healer).

In the first book published by the Magnet Theatre (The Magnet Theatre 'Migration' plays, edited by Reznek, J., Fleishman, M., Yisa, F. and F.Marek in 2012), the four texts mentioned above are given in full with programme notes for each. These works have been performed locally and internationally on a regular basis, received a lot of acclaim and awards. For example, the first play in the book, Every Year, Every Day, I am walking had its first performance in 2006 in 
Cameroon, but has since been staged in numerous venues in Southern Africa and also internationally.

Yvette Hutchison, in her discussion of the Magnet theatre's migrant plays (in The Methuen Drama Guide to Contemporary South African Theatre, 2015: 70) highlights their use of images and physical theatre to portray the plight of migrants for audiences:

The style of physical theatre, with its combination of narrative alongside vivid and poignant images, movement and music, invites audience members to engage imaginatively with what they see in the space, while acknowledging the fact that these are affective indicative gestures that work on an embodied somatic level to hint at experiences ubiquitous to migrancy and being a refugee.

Another book on this group's work was published in 2016 and launched at the IFTR 2016 conference held in Stockholm, namely: Magnet Theatre: Three Decades of Making Space (ed. Anton Krueger \& Megan Lewis). This book also refers to the four plays mentioned above, but also sets out in three parts (Part One - Concepts: Making space for ideas; Part Two - Collaboration: Making space for embodied practice; and Part Three-Community: Making space for cultural interventions) the philosophical underpinning and viewpoints of this group. 
There has been an upsurge in migrant plays in South Africa in the last few years (often within the genre of verbatim theatre). According to Micki Flockeman (2017:

3): "it was striking how many works at the annual National Arts Festival in Grahamstown this year (2016) engaged implicitly or explicitly with notions of South African identities in terms of belonging and migrancy, locally and across Africa". She also mentions that the "2008 xenophobic attacks have featured strongly in performances dealing with the experiences of migrancy", for example, Gina Schmuckler's verbatim piece The Line (2012) “which draws on unedited interviews with perpetrators, victim-survivors and witnesses to the attacks which began in Alexandra township in Johannesburg" (3). Particularly shocking is the fact that the "foreigners" who were targeted were in fact neighbours, living in nextdoor shacks, who were from bordering Southern African states like Mozambique.

Flockeman (2017: 3) also refers to Anton Krueger's assessment of the rise of migrant theatre in South Africa as so prevalent that it should be recognized as the emergence of a new theme in recent South African theatre. One playwright who has written on the topic, is Mike van Graan. He wrote a satirical revue Pay Back the Curry! which was also performed at the 2016 National Arts Festival in Grahamstown festival. The focus in this article is, however, on his 2017 play, When Swallows Cry.

Mike van Graan's When Swallows Cry 
Mike van Graan is one of the leading contemporary playwrights in South Africa. He has written and staged a large number of plays (a total of 27) and has received numerous awards and accolades for his work. His work is characterised by a deep concern for social justice and some of the topics he explores in his work are racism, corruption, humanism, migration, environment, and xenophobia.

According to Van Graan the origin for the play, When Swallows Cry, is linked to a Norwegian theatre company (Ibsen International) led by Inger Buresund who has been working in China for a number of years. A project of them, called "New Text - New Stage", promoted the creation of new dramatic texts, as well as their productions. In 2015 they decided to concentrate on the theme of migration, because of its current international importance. They invited eight playwrights from four different continents (Europe, Asia, North America and Africa) to an initial meeting in Beijing, followed by further meetings in Shanghai and Guangzhou over a period of nine months, in which these playwrights developed their respective texts. Since 2015 these texts have been produced by different theatres in various countries. When Swallows Cry premiered in January 2017 in Johannesburg, Market Theatre and has since then been performed locally and internationally to great acclaim.

The play itself is made up of three "playlets" that are inter-spliced with each other and pick up on different themes related to migration. 
(1) The main story features a "migrant" Canadian teacher - initially assumed to be an American - who is captured by a group of bandits in a West African country. He is held ransom to generate the funds required to develop the region in which he is held. As more information about who he is emerges, the leader of the bandit group (Commandant) decides to kill him, but the ordinary soldier does not see the sense in such an act. Eventually the soldier turns on Commandant and releases the hostage. In the end, when he is presented with an opportunity to do so, the Commandant decides not to shoot the Soldier.

(2) A second story features two Zimbabwean teachers who flee the economic hardships and the political oppression of their country in a boat heading to Fiji where they will not require visas for at least three months. However, the boat ventures into Australian waters and they are held at a detention centre for illegal immigrants, and are marked for immediate deportation to Zimbabwe. They manage to capture their racist detention officer but realise that they are unable to escape. The detention officer regains control, and the two refugees are shot dead.

(3) The third story tells of a Somalian who leaves his war-torn country for South Africa, only to experience brutal xenophobic violence that obliges him to seek refuge in America. He obtains a legitimate US visa but is hounded at 
the port of entry. One of his tormentors (ironically) is an African- American official, a descendant of African slaves, but whose job it is to prevent "undesirables" entering America. The officials refuse him entry - and rather than returning to the countries he has fled, the Somalian kills himself with one of the official's gun.

These three playlets develop simultaneously (each playlet follows the same structure one after another; i.e. a short, but powerful exposition of each playlet; a rapid escalation of events towards confrontation between the characters and the final climatic ending of each playlet). The play is thus made up of 9 scenes with scenes $1-3$ setting the dramatic situations for each of the 3 playlets, scenes 4-6 developing these situations and increasing the dramatic tension through verbal and physical for each playlet, and in scenes $7-9$ bringing each the playlets to a climatic end. It thus seems to the reader/spectator of this play as if these scenes are all taking place simultaneously in different parts of the world and in each case one is made aware of how full of complexities and ironic ambiguities these situations are. Van Graan also stated in his stage directions that the roles of the two black and one white male characters should be performed by the same three actors throughout the performance. By switching their roles constantly through-out the performance one also gets the situation that an actor can play a "good" character in scene one (eg the idealistic Canadian teacher, Charles Stevenson) and that the same 
actor can play in scene two a racist and xenophobic detention officer at a USA airport (Clark). By using this device Van Graan is implicitly demonstrating (without having to explicitly state the obvious) that one can find "good" and "bad" people in any race and country.

Although Van Graan has not situated these three playlets in South Africa, one finds in each one some South African references. The most brutal example is given in Playlet 1 where Commandant puts a tyre around Charles' neck and pours petrol over him (the so-called necklace murders that infamously took place in South Africa in the 1980's):

Commandant: this we learn from South African brothers. I know ... you ... your world say ... barbarians! How can kill someone like that? How can watch someone burn? Civilized world, Soldaat ... they drop bombs. They drone death. They nuclear cities. Kill tens. Hundreds. But we ... we barbarians (47).

Reviews of the play were positive and reviewers often commented on how spectators were confronted with the human face of migrants. Lesley Stone (2017: 1) in her review for the Daily Maverick highlights this aspect in the title of the review: "When Swallows Cry shows that migrants lives matter". Etienne Shardlow's review in Artsvark (2017: 1) also comments on how the play 
humanizes migrant and refugee statics and newspaper reports, and how spectators are thus confronted with a reality that is brutal, but also complex:

This play, tells three separate stories on three different continents, each dealing with people in foreign countries and their violent interactions with locals. Each of these stories makes the audience uncomfortable, raising issues of privilege, xenophobia and prejudice. We hear similar stories regularly as part of news reports, we read about events like these in the papers or online weekly, sometimes more frequently, and we have become numb to the emotions they should evoke, anger, sadness, frustration. This work takes these stories and makes them real to the audience, making the characters real, letting the characters speak for their actions, and in this wakes the audience to some of the shocking realities lived daily in our world. The beauty in this piece by Mike van Graan is that the play makes no judgement, it tells the stories and allows the characters to speak for themselves. Letting the audience judge, if they so wish.

Interestingly in some of the post-performance discussions held with audiences Van Graan was criticized on a number of issues by audience members who disagreed with his portrayal of black characters in these playlets. Van Graan himself wrote a quite substantial response "to the critiques that all the black characters die in When 
Swallows Cry and the pessimistic messages that this conveys" (online: Just another Word/Press.com site). In this lengthy response (5 pages) he mentions 4 "aims" that this play set out to achieve:

(1) To face up to the "uncomfortable truth in post-apartheid South Africa, that black people kill other black people". He gives some statistics in this regard to prove his point, i.e. "that more than 40 black people are murdered each day in South Africa - overwhelmingly by other black people";

(2) To confront the tendency to "view everything through the lens of race". The reason why he chose to write three stories with three characters (one white and two black) playing completely different characters in each story;

(3) To focus on "power relations", i.e. the power relations are unequal in all 3 stories between "the captured" and "the captors"; and

(4) To explore the notion of "being civilized and acting in a civilized way". Western countries often deem themselves to be "civilized" and those countries who act contrary to their western values and standards are deemed to be barbarians, uncivilized, etc.

Van Graan dismisses the notion that one can only write about one's own "stories"/world. He believes that a writer only "requires human empathy", his own imagination and to do some research - to write about other people's stories. For him When Swallows Cry is about "human beings in and from Africa". 
Van Graan's play thus reflect a changing focus in migrant plays in South Africa: from the very early plays concerned with internal migration in the country to plays that today reflect a more complex world (i.e. the often violent and xenophobic experiences of African migrants - also within a so-called new South Africa, but also in the rest of Africa and the bigger world).

Cox (2014: 27) in her discussion of how audiences often experience migrant theatre states that:

The way an audience member interprets and responds to any piece of theatre is influenced by the way he or she imagines his or her relationship to the artists that made the work, and to the story being told. In theatre of migration this may be summed up, crudely, as 'Is it by/about them or is it by/about us?' (although in practice, affiliations are rarely so straightforward).

\section{Conclusion}

Today globally the issues of migration and refugees are of huge sociopolitical, humanitarian and cultural importance and affects the lives of millions of people. Some theorists approach the whole issue of migration from particular theoretical positions (see, for example, the rise in diaspora studies in current discourses), but for other theorists (for example Cox) the basic premise has always been how 
audiences experience theatre and how the spectator is affected by portrayals of situations and characters that confront issues of social and individual concern.

Theatre has always reflected what is happening in society and audiences have always been confronted with various socio-political issues impacting on society, but also on individuals (see Hauptfleisch,1997). It is probably naïve and unrealistic to think that plays and performances can change attitudes and beliefs on a substantial scale (see Hauptfleisch in terms of the impact of theatre, 1997: 104114). It is, however, also true (as Cox has demonstrated in her seminal book on Migration theatre through a discussion of numerous examples) that the "stories" of the individual (the "character/s") do affect the spectator on various levels (inter alia, emotionally and intellectually).

When one is confronted on a global scale - but even in South Africa on a local scale - by the statistics of migration the sheer number of people living the reality of being migrants can be experienced as an overwhelming and perhaps abstract notion. In plays, and specifically in Van Graan's When Swallows Cry, we are confronted with characters and stories which make the statistics personal and individual. We may or may not accept the playwright's portrayal of these people and their socio-cultural contexts, but we will be confronted with issues (racism, xenophobia, the Other, the concepts of home and foreignness, etc.) that do impact on our daily lives. 
One can only hope as Van Graan (2017: 5) states in his closing remarks "that audiences will think more, analyse deeper and reflect longer on all the issues surrounding migration" - and then finally "to act as empathetic humans in a world and in a society where such action is increasing necessary, but also increasingly difficult to find".

\section{References}

Africa Check : Online: $<$ https://africacheck.org/factsheets/geography-migration/ >. 30 January 2020.

Ahmed, S. 2000. Strange encounters: embodied others in post-coloniality. London: Routledge.

Balfour, M. 2013. Refugee performance: practical encounters. Chicago Il: Univ of Chicago.

Bhabba, H. 1994. The location of culture. London: Routledge.

Cox, E. 2014. Theatre and migration. New York: Palgrave MacMillan.

Crush, J. and G. Tawodzera. 2014. Medical xenophobia and Zimbabwean migrant access to public health services in South Africa. Journal of Ethnic and Migration Studies 40 (4), 655-670. 
Erwin, K. 2017. Migration and the Inclusive city: Migration and social inclusion

Flockemann, M., Roberts, W., Castle, A., Krog, A. \& K. Ngara. 2009. Performing xenophobia: a conversation with Jonathan Nkala and Bo Petersen. Theatre Journal, 23 (1): $207-220$.

Flockemann, M. 2017. I am/am I an African? A relational reading of Diaspora and Identity in South African fiction by J.U. Jacobs (Review article). In: Literator $38(1)$.

Greenburg, J. 2010. The spatial politics of xenophobia: everyday practices of Congolese migrants in Johannesburg, Transformation: Critical perspectives on Southern Africa 74, 66-86.

Gunner, L. (ed). 1994. Politics and performance: Theatre, poetry and song in Southern Africa. Johannesburg: Witwatersrand University Press.

Hauptfleisch, T. 1997. Theatre \& Society: Reflections in a fractured mirror. Pretoria: J.L. van Schaik.

Hutchison, Y. 2015. Chapter 3: Contemporary collaborators II: Magnet theatre. In: The Methuen Drama guide to Contemporary South African theatre. Middeke,M., Schnierer,P.P. \& G. Homann (eds). London: Bloomsbury Methuen. 
IFTR (International Federation for Theatre Research) programme: www.iftr.org/news/2018/june/iftr-2018-world-congress-final-programme , 30 January 2020.

Joubert, E. 1978. Die Swerfjare van Poppie Nongena. Kaapstad: Tafelberg Uitgewers.

Joubert, E. \& S. Kotzé. 1984. Poppie - die Drama. Kaapstad: Tafelberg Uitgewers.

Klotz, A. 2000. Migration after apartheid: deracializing South African foreign policy, Third World Quarterly 21(5), 831-847.

Lewis, M \& A. Krueger. 2016. Magnet theatre: Three decades of making space. Pretoria: UNISA University of South Africa Press.

Middeke,M., Schnierer,P.P. \& G. Homann (eds). 2015. The Methuen Drama guide to Contemporary South African theatre. London: Bloomsbury Methuen.

Peberdy, S. 2001. Imagining immigration: inclusive identities and exclusive policies in post 1994 South Africa, Africa Today 48(3),15-32.

Reznek, J., Fleishman, M., Yisa, F. and F.Marek. 2012. The Magnet Theatre 'Migration'plays. Mowbray: Junkets Publisher.

Shardlow, E. 2017. Artsvark review. Online: < www.artsvark.co.za/review-whenswallows-cry >. 30 January 2020. 
Small, A. 1965. Kanna hy kô hystoe. Kaapstad: Tafelberg Uitgewers.

Stones, L. 2017. When swallows cry shows that migrants lives matter. Review.

Online. $<$ www.dailymaverick.co.za/article/2017-01-23-theatre-review-when-

swallows-cry-shows-that-migrants-lives-matter $>.30$ January 2020.

Van Graan, M. 2017. When Swallows Cry. Unpublished script emailed by author.

Van Graan, M. 2017. A response to the critique that "all the black characters die" in When Swallows Cry and the pessimistic messages that this conveys. Online:

WordPress.com site. $<$ https://mikevangraan.wordpress.com/2017/02/27/a-

response-to-the-critique-that-all-the-black-characters-die-in-wen-swallows-cryand-the-pessimistic-messages-this-conveys >. 30 January 2020.

Von Kotze, A. 1988. Organise and act. The Natal Worker's Theatre movement 1983 - 1987. Durban: Culture and Working Life Publications. 